\title{
Influence of Psychological Factors, Social Factors and Physical Factors on Student Satisfaction that Impacts on Lecturer Performance in Private Universities in Palembang City
}

\author{
Lesi Agusria and Wani Fitriah \\ Faculty of Economics and Business, Muhammadiyah University of Palembang \\ Lesi.agusria@gmail.com, wanifitriah61@gmail.com
}

\begin{abstract}
This research discusses the formulation of whether the influence of psychological factors, physical factors and social factors on Student Satisfaction impacted the performance of lecturers at Private Universities in Palembang City. This type of research is associative using samples of 245 students with sampling techniques using probability sampling. The data used in this study is primary data collected through the Kuesioner method. Data analysis techniques are performed with multiple linear regression two models using SPSS ver.26. The results showed that (1). Psychological factors have a significant effect on student satisfaction at Palembang City Private College, and there is an indirect influence of psychological factors (X1) through Student Satisfaction (Y) on lecturer performance (2). Social factors have a significant effect on student satisfaction at private universities in Palembang, and there is an indirect influence of social factors (X2) through Student Satisfaction (Y) on lecturer performance (3). Physical factors have a significant effect on student satisfaction in private universities in Palembang city, and there is an indirect influence of physical factors (X2) through Student Satisfaction (Y) on lecturer performance (Z)
\end{abstract}

Keyword: Psychological factors, Physical factors, Social factors, Student Satisfaction,

Performance of lecturer

\section{How to cite}

Agusria, L, and Fitriah, W. (2021). Influence of psychological factors, social factors and physical factors on student satisfaction that impacts on lecturer performance in private universities in the City of Palembang. International Journal of Business, Management and Economics, 2(2), 89-101. DOI: https://doi.org/10.47747/ijbmer.v2i2.237.

\section{Introduction}

\subsection{Problem Background}

Human resources are resources that play an active role in running an organization through the decision-making process. Managing human resources cannot be seen as an independent part but 
must be seen as a strong unit forming a synergy of all elements in management. Human resources are the only resources with a sense of feeling, desire, skill, knowledge, encouragement, power, and work (ratio, taste, and intention). All of these potential human resources affect the organization's efforts to achieve one goal. Therefore, managing professional human resources requires skills. The management starts from the recruitment, selection, classification process to the employee placement process. The placement process needs to adjust to the abilities, expertise, skills, and career development because managing professional human resources done because of the development of the business world today, where every business organization is required to create high employee performance to win a competitive advantage. For this reason, the company must be able to build and improve performance in its environment; then, it can be said that the company is successful.

According to Armstrong and Baron (in Wibowo, 2016: 7), performance is the result of work that has a strong relationship with strategic goals, employee satisfaction and contributes to the economy. Meanwhile, according to Bintoro and Daryanto (2017:106), performance is the result or level of success of a person as a whole during a particular period in carrying out tasks compared to various possibilities, such as work standards, targets or targets or criteria that have been previously agreed upon. Sutrisno (2017: 75) suggests job satisfaction is an emotional state that is pleasant or unpleasant for employees to view their work, and also suggests that psychological factors are related to employee psychology, including interests, peace of mind at work, talents, and skills. Job satisfaction will have an impact on the birth of good performance as well. This is in line with Bintoro and Daryanto (2017: 91) opinion, who argues that job satisfaction is an emotional attitude that is pleasant and loves his job.

Several factors can affect job satisfaction, including psychological factors, social factors and physical factors. The psychological factors in question are factors related to the employee's psyche, including interests, peace of mind at work, attitudes towards work, talents and skills. Social factors are factors related to social interactions, interactions between employees and superiors and employees with different types of work. Physical factors are factors related to the physical condition of the work environment and the physical condition of employees, which includes the type of work, time and rest time, and work equipment. Work equipment includes the condition of the room, temperature, lighting, air exchange, health condition of employees, age.

Priansa (2018:294) notes the various impacts of job satisfaction on performance according to several experts, including the following:

a) Jacobs and Solomon (Spector, 1997) stated that the correlation between job satisfaction and performance would be higher in jobs that do not provide rewards. In such conditions, employees who have good performance get rewards, which leads to job satisfaction. Consistent with their predictions, Jacobs and Solomon found that performance and job satisfaction were strongly related when organizations rewarded good performance.

b) Robbins (2006) states that employee work productivity leads employees to job satisfaction. If employees do their jobs well, the organization will appreciate their productivity. Awards given by the organization can be in salaries or promotions, which can then lead to employee satisfaction at work. Therefore, it can be said that employees who are happy and satisfied with their work will be more productive. Conversely, if employees are not satisfied with their work, their productivity is also low. 
The above formulation applies to all business organizations, including universities, one of which is private universities. Private universities are universities that are owned and managed by individuals or groups or certain foundations. Private universities in financing the management and implementation of education are the full responsibility of the universities concerned. The government only serves as supervision and provision of curriculum provisions in the learning process with applicable laws.

Examining the factors that influence satisfaction at private universities in the city in Palembang found that the psychological factors that occur in private universities in the city in Palembang are factors related to (a) interest, which is a reference that can develop student learning potential more effective. Lack of interest in learning can affect students in completing their assignments. (b) peace, teaching and learning activities for students is something that must be fulfilled so that the learning process activities can run smoothly. On social factors, which occurs in private universities in Palembang City, is a factor related to the social interaction of fellow employees with superiors. Here can be interpreted as the social interaction of students with lecturers. Implementation interaction between superiors and subordinates requires proper implementation because if it is not conveyed properly, it will hinder its work. Physical factors in private universities in Palembang City are factors related to the room or classroom layout condition. Classroom layouts that are less effective and less comfortable will make students not fully satisfied in learning.

This study begins with several pre-research steps to ensure that the phenomena that occur are related to the performance of lecturers obtained from student satisfaction. The results of the research found that private universities students in Palembang City argued that lecturers in teaching often pressured students to follow the flow of their teaching style, and students were required to adjust the directions that the lecturer had set to make students uncomfortable and disrupt the peace in the learning process. The attitude towards work and the lecturer's concern for students are still not going well. Errors in learning often occur when the lecturer gives a confusing task without giving further direction and guidance. Lecturers do not provide the correct solution but instead scold their students; the impact of no harmony in the interaction can hamper the teaching and learning process. On the physical factors that occur in the private universities in Palembang City, there are still complaints about the condition of the room or classroom layout, where students feel that the spatial layout is not comfortable, related to the facilities and infrastructure. This makes students not fully get satisfaction in learning. The narrow classroom layout makes the atmosphere and condition of the room even more unfavourable.

The movement of students is limited by the inadequate condition of the room. The impact of no harmony in the interaction can hinder the teaching and learning process. On the physical factors that occur in private universities in Palembang City, complaints are still found about the room or classroom layout condition, where students feel that the spatial layout is less comfortable, related to the facilities and infrastructure. This makes students not fully satisfied with learning. The narrow classroom layout makes the atmosphere and condition of the room even more unfavourable. The movement of students is limited by the inadequate condition of the room. The impact of no harmony in the interaction can hinder the teaching and learning process. On the physical factors that occur in private universities in Palembang City, complaints are still found about the room or classroom layout condition. Students feel that the spatial layout is less comfortable, related to the facilities and infrastructure. This makes students not fully get 
satisfaction in learning. The narrow classroom layout makes the atmosphere and condition of the room even more unfavourable. Students' movement is limited by the inadequate condition of the room and related to the facilities and infrastructure. This makes students not fully get satisfaction in learning. The narrow classroom layout makes the atmosphere and condition of the room even more unfavourable. Students' movement is limited by the inadequate condition of the room and related to the facilities and infrastructure. This makes students not fully get satisfaction in learning. The narrow classroom layout makes the atmosphere and condition of the room even more unfavourable. The movement of students is limited by the inadequate condition of the room.

Student satisfaction at private universities in Palembang is a factor related to loyalty, namely students have an emotional sense of lecturers so that learning is not just a matter of professionalism; this makes students unable to think optimally when there are innuendos that are made when in class. Teaching and learning process. Next is the ability factor. Namely, students try hard to be accepted in the classroom environment; students who experience this usually become forced in their studies. Students cannot do it if given the task of learning loads that are not by their capacity, position, and responsibilities. Then the honesty factor, at private universities in Palembang City, there is intimidation by lecturers in the learning process. The purpose of this intimidation is to make students understand the material presented faster. However, this can cause students to be afraid of learning, and in the end, students will try to meet the demands of learning by using various methods, although using a different method. The next more factor is leadership, which discusses the question of the behaviour of lecturers who do not show respect for students and the lack of interaction and socialization between lecturers and students. The results of the student learning process do not run smoothly. Finally, the work environment factor, which can be interpreted as a class environment, incomplete supporting facilities can result in a lack of comfort for students.

Lecturer performance that occurs in private universities in Palembang City is a factor related to:

1) Objectives, namely the lack of clear goals that hinder lecturer performance, tools or facilities owned by lecturers in private higher education in Palembang City, are less than optimal and incomplete to be less efficient in the teaching and learning process.

2) The competencies, motives and opportunities possessed by lecturers at private universities in Palembang City are relatively qualified, but the lack of higher competencies makes lecturers capable of being ignored.

Does this study formulate the problem is there any influence of psychological factors, physical factors and social factors on student satisfaction that impact lecturer performance? At the same time, it aims to determine the influence of psychological factors, social factors, and physical factors on student satisfaction, impacting lecturer performance at private universities in Palembang City.

\section{Lierature Review}

\subsection{Theoretical Foundation}

According to Bintoro \& Daryanto (2017: 48), the needs of employees are not merely to fulfil material needs such as a decent salary and a sound career, but are more diverse such as the need for self-esteem and authority, job satisfaction, and the need to adapt. Bintoro and Daryanto (2017: 91) also states that job satisfaction is an emotional attitude that is pleasant and loves his 
job. This attitude is reflected by work morale, discipline and work performance. Job satisfaction is enjoyed at work, outside of work, and a combination of inside and outside work. The factors that influence job satisfaction are psychological, social factors, physical factors and financial factors. Meanwhile, according to Hasibuan (2019: 202), job satisfaction is emotional; he is fun and loves his job.

a) Loyalty

Assessment measures employee loyalty to his job, position, and organization. This loyalty is reflected by the willingness of employees to maintain and defend the organization inside and outside of work from the undermining of irresponsible people.

b) Ability

The appraiser assesses the work results both in quality and quantity that the employee can produce from his job description.

c) Honesty

The appraiser assesses honesty in carrying out his duties to fulfil the agreement for himself and others.

d) Creativity

The appraiser assesses the ability of employees to develop their creativity to complete their work so that they will be able to work better.

e) Leadership

Assessors assess the ability to lead, have a strong personality, are respected, authoritative, and can motivate others or their subordinates to work effectively.

f) Salary Level

Appraisers assess the amount of salary given by the company and received by employees according to what employees give to the company to feel satisfied.

g) Indirect compensation

Appraisers assess providing adequate and appropriate remuneration to employees for their contribution to helping the company achieve its goals and, for example, giving remuneration or compensation for the energy, time, thoughts and achievements that have been given by someone to the company.

h) Work environment

Appraisers assess that a good work environment can make employees feel comfortable at work.

Psychological Factor. According to Herzberg (Busro, 2018: 110), psychological factors are factors related to a person's psyche. Bintoro and Daryanto (2017: 92) suggests that there are several indicators of psychological factors, including:

a) Interest is a person's awareness or interest in an object, person, problem, or situation related to a person.

b) Peace at work is a feeling of security and calm in doing a job

c) Attitude is a condition in humans that moves to act or act in a job with certain feelings in response to situations and conditions of the surrounding environment.

d) Talent is an innate ability that is a potential that still needs to be developed or trained to achieve a particular skill, knowledge and skill.

e) Skill is the ability that a person has in doing and completing a job. 
Social factors. According to Herzberg (in Busro, 2018: 110), social factors are factors related to social interactions, both among employees with superiors and employees with different types of work. The indicators of social factors according to Sutrisno (2009:82) are:

a) A family relationship is a relationship between each entity with the exact genealogical origin, either through biological, social or cultural descent.

b) Job View deals with skills, mindsets, attitudes, complex processes, and reasonable expectations.

c) Political freedom, namely the right to vote and the right to superior public positions, freedom of speech and assembly, freedom of conscience and freedom of thought, freedom to own property.

d) Public relations is an effort to build and maintain a good and beneficial reputation, image and communication between the organization and the community.

Physical Factors. According to As'ad (in Sutrisno, 2017: 80), physical factors are factors related to the physical condition of the work environment and the physical condition of employees, including types of work, work and rest time arrangements, work equipment, room conditions, air temperature, lighting, air exchange, employee health condition, age and so on.

Research using similar variables has been recorded by various researchers, including those used as references in this study are:

a) Syaharuddin (2016) entitled factors affecting job satisfaction and employee performance of Bank Muamalat Samarinda Branch. This study concludes that leadership has a positive and significant effect on job satisfaction of Bank Muamalat employees, the work environment has a positive and significant effect on job satisfaction of Bank Muamalat employees, organizational commitment has a positive and insignificant effect on job satisfaction of Bank Muamalat, job satisfaction has a positive and significant effect on employee performance Bank Muamalat, leadership has a positive and significant direct effect on performance while indirectly through job satisfaction on performance has a positive effect on the performance of bank Muamalat employees,

b) Verawati, Y and Saptarini (2017), entitled the influence of financial factors, social factors, and psychological factors on employee performance at LPD Kesiman Denpasar, found the results of his research that both financial factors, social factors and psychological factors simultaneously had a significant effect on employee performance, indicated by sig. $\mathrm{F}=0.00$, which was less than $5 \%$. The magnitude of the influence of these three variables on employee performance is 0.608 or $60.8 \%$, while the remaining $39.2 \%$ is explained by other factors not included in the research model.

c) Norianggono, Djamhur Hamid, Ika Ruhana (2014), entitled the influence of the physical and non-physical work environment on employee performance (Study on employees of PT. Telkomsel Area III Java-Bali Nusra in Surabaya), The results showed that the physical work environment variable had a significant influence. Significant and positive effect on employee performance variables and non-physical work environment variables have no significant effect on employee performance variables. The physical work environment and non-physical work environment simultaneously have a significant influence on employee performance, which means that if the physical work 
environment and non-physical work environment run well together, it will increase the performance of PT. Telkomsel Area III Java-Bali Nusra Surabaya city.

\subsection{Hyphotesis}

Furthermore, this research departs from the hypothetical thinking:

$\mathrm{H}_{0}$ : There is no influence of psychological factors, social factors, and physical factors on student Satisfaction, which impacts the performance of lecturers at private universities in Palembang City.

Ha: There is an influence of psychological factors, social factors, and physical factors on student satisfaction, which impacts the performance of lecturers at private universities in Palembang City.

\subsection{Thinking Framework}

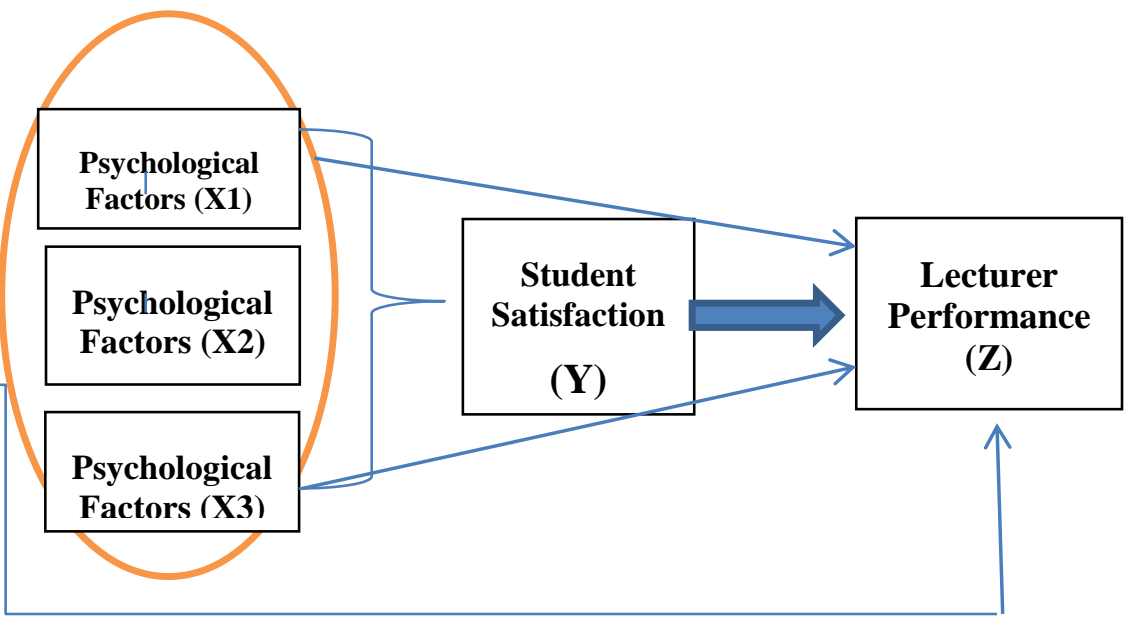

Figure 1. Thinking Framework

\section{Research Method}

This research is associative research with variables consisting of :

1. Variable Z: Lecturer Performance

Indicators: objectives, standards, feedback, tools and means, competencies, opportunities

2. Variable Y: Student Satisfaction

Indicators: loyalty, ability, honesty, leadership, work environment

3. Variable X1: Psychological Factor

Indicators: interest, peace, attitude

4. Variable X2: Social Factor

Indicators: interaction with fellow students, interaction with lecturers, interaction with employees

5. Variable X3: Physical Factor

Indicators: timing, equipment/facilities, state of the room

This research was conducted in Palembang City, using private universities spread across the

Seberang Ulu and Seberang Ilir areas in Palembang City as research objects consisting of: 
1) Tridinanti University, Jl. Captain Marzuki No.2446,20 Ilir DII, Kec. Ilir Team. I, Palembang City, 30129.

2) Musi Charitas University, J1. Bangau No. 60.9 Ilir, Kec. Ilir Tim. II, Palembang City, 3011.

3) Indo Global Mandiri University (IGM), Jl. Jend. Surdiman No.4, 20 Ilir D.IV, Ilir Timur I, Palembang City, 30129

4) Muhammadiyah University of Palembang, JL. General Ahmad Yani, Seberang Ulu, Kec. Plaju, Palembang City

5) PGRI University JL. General Ahmad Yani, Seberang Ulu, Kec. Plaju, Palembang City

6) Bina Darma University, JL. General Ahmad Yani, Seberang Ulu, Kec. Plaju, Palembang City

A descriptive research survey design was adopted in this study. This research design shows the state of affairs as it exists at present. The choice of this research design was motivated by the instrument's suitability to collect a large amount of data. The study involved students, lecturers and administration staff in the university. The researcher appointed research assistants who have engaged in the distribution the administration of the questionnaires. A self-designed questionnaire that entailed structured and unstructured questions was administered to all the respondents. Whereas definite responses were obtained from the structured questions, the unstructured questions allowed the respondents to express themselves. Descriptive statistics were used and statistical output was generated using SPSS version 25.

The population used in this study were active students of private universities in the city of Palembang, totalling 23,739 people, and the sample used in this study was 245 people who were determined by probability sampling technique taken from simple random sampling with the following details:

Table 1. Population and Sample Distribution

\begin{tabular}{|l|l|l|l|}
\hline No & \multicolumn{1}{|c|}{ College student } & Population & Sample \\
\hline 1 & Tridinanti Univ & 2.294 & 47 \\
\hline 2 & Univ Musi Charitas & 2.416 & 49 \\
\hline 3 & IGM Univ & 1.447 & 29 \\
\hline 4 & Univ.Muhammadiyah & 9.207 & 63 \\
\hline 5 & Univ. PGRI & 6.769 & 46 \\
\hline 6 & Univ. Bina Darma & 1,606 & 11 \\
\hline Amount & 23,739 & 245 \\
\hline
\end{tabular}

The data used are primary data obtained through questionnaires distributed to respondents at private universities in Palembang City. Data analysis was carried out using multiple linear regression analysis (2) models with intermediation variables assisted by SPSS version 26. Tests were carried out in the following stages:

1. Testing the variables $\mathrm{X} 1, \mathrm{X} 2, \mathrm{X} 3$ against $\mathrm{Y}$

2. Testing the variables $X 1, X 2, X 3$ against $Z$

3. Testing the variables $\mathrm{X} 1, \mathrm{X} 2, \mathrm{X} 3$ through $\mathrm{Y}$ against $\mathrm{Z}$ 


\section{Results And Discussion}

\subsection{Research Results}

\subsubsection{Instrument Test}

a. Validity test

All construct indicators are declared valid when the loading factor value generated for all indicators is 0.50 or t-value 1.96 , except for indicators with a loading factor value of 0.5 or tvalue 1.96, so it must be removed for further data analysis. Calculations to test the validity in this study using the LISREL program. 8.70.

\section{Reliability Test}

Reliability (reliability test) shows the extent to which a measuring instrument can provide relatively the same results when repeated measurements are made on the same subject. The level of reliability that is accepted is if the construct reliability value is 0.70 .

\subsubsection{Testing Process}

a. Model regression Testing

Table 2. Coefisien of Determination

\begin{tabular}{|l|l|l|l|l|}
\hline \multicolumn{5}{|c|}{ Model Summary } \\
\hline Model & $\mathrm{R}$ & $\begin{array}{l}\mathrm{R} \\
\text { Square }\end{array}$ & $\begin{array}{l}\text { Adjusted } \\
\text { R Square }\end{array}$ & $\begin{array}{l}\text { Std. Error of } \\
\text { the Estimate }\end{array}$ \\
\hline 1 & ,394a &, 155 &, 145 & 3,159 \\
\hline \multicolumn{3}{|l|}{ Predictors: (Constant), X1, X2, X3 } \\
\hline
\end{tabular}

Table 3.Multiple Linear Regression

\begin{tabular}{|c|c|c|c|c|c|c|}
\hline \multicolumn{2}{|c|}{} & \multicolumn{2}{|c|}{$\begin{array}{c}\text { Unstandardized } \\
\text { Coefficients }\end{array}$} & $\begin{array}{c}\text { Standardized } \\
\text { Coefficients }\end{array}$ & T & Sig. \\
\hline \multirow{4}{*}{1} & B & Std. Error & Beta & & \\
\hline \multirow{3}{*}{1} & (Constant) & 12,625 & 1,470 & & 8,586 &, 000 \\
\cline { 2 - 8 } & X1 &, 145 &, 074 &, 133 & 1,963 & 0.051 \\
\cline { 2 - 7 } & X2 &, 134 & 0.099 &, 101 & 1,359 &, 175 \\
\hline
\end{tabular}

a. Dependent Variable: Y

Referring to Table 2. it can be seen that the $\mathrm{R}$ Square value of 0.155 indicates that the contribution of psychological factors, social factors and physical factors to student satisfaction is only $15.5 \%$, and the remaining $84.5 \%$ is influenced by other variables that are not included. In this research. Meanwhile, the value of e1 is obtained at $(1-0.155)=0.919$. Thus, the model I test path diagram is obtained as follows: 


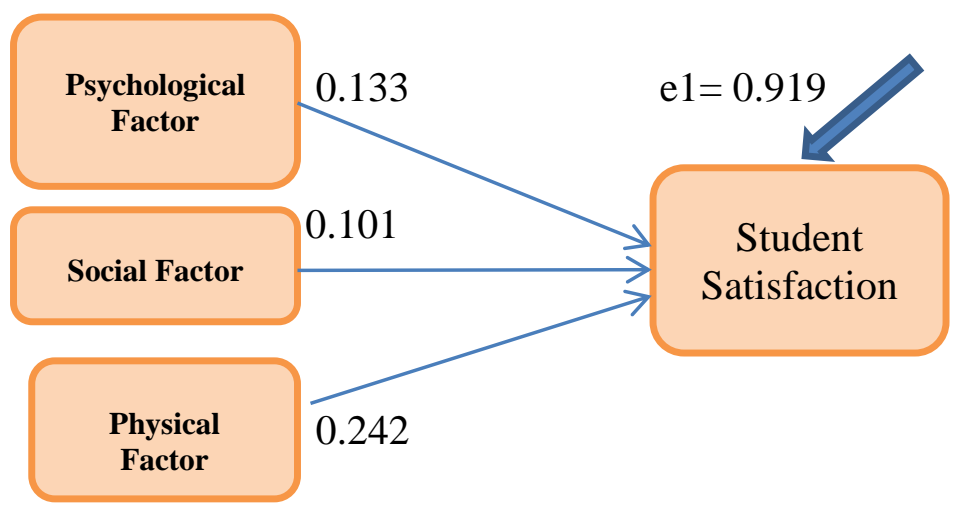

Figure 2. Regression Result

b. Model II Regression Test

Table 4 Coefficient of Determination

\begin{tabular}{|l|r|r|r|r|}
\hline \multicolumn{5}{|c|}{ Model Summary } \\
\hline Model & $\mathrm{R}$ & $\begin{array}{c}\mathrm{R} \\
\text { Square }\end{array}$ & $\begin{array}{l}\text { Adjusted } \\
\text { R Square }\end{array}$ & $\begin{array}{r}\text { Std. Error of } \\
\text { the Estimate }\end{array}$ \\
\hline 1 &, $694 \mathrm{a}$ &, 481 &, 473 & 2,563 \\
\hline
\end{tabular}

a. Predictors: (Constant), Y, X1, X2, X3

Table 5 Multiple Linear Regression

\begin{tabular}{|c|c|c|c|c|c|}
\hline \multicolumn{6}{|c|}{ Coefficientsa } \\
\hline \multirow[t]{2}{*}{ Model } & \multicolumn{2}{|c|}{$\begin{array}{l}\text { Unstandardized } \\
\text { Coefficients }\end{array}$} & \multirow{2}{*}{$\begin{array}{c}\text { Standardized } \\
\text { Coefficients } \\
\text { Beta }\end{array}$} & \multirow[t]{2}{*}{$\mathrm{t}$} & \multirow[t]{2}{*}{ Sig. } \\
\hline & B & $\begin{array}{l}\text { Std. } \\
\text { Error }\end{array}$ & & & \\
\hline 1 (Constant) & 4,215 & 1.363 & & 3.092 &, 002 \\
\hline $\mathrm{X} 1$ &, 222 & 0.060 & , 197 & 3,668 &, 000 \\
\hline $\mathrm{X} 2$ & ,438 & 0.080 & ,318 & 5,457 &, 000 \\
\hline $\mathrm{X} 3$ & ,300 & 0.069 & ,273 & 4,341 &, 000 \\
\hline $\mathrm{Y}$ & 115 & 0.052 &, 111 & 2,201 & 0.029 \\
\hline
\end{tabular}

a. Dependent Variable: $\mathrm{Z}$

Referring to Table 4 it can be seen that the $\mathrm{R}$ Square value of 0.481 indicates that the contribution of the variable psychological factors, social factors and physical factors and student satisfaction on lecturer performance is $48.1 \%$, and the remaining $51.9 \%$ is influenced by other variables. not included in this study. Meanwhile, the value of e2 is obtained at (1$0.481)=0.7204$. Thus, the model II test path diagram is obtained as follows: 


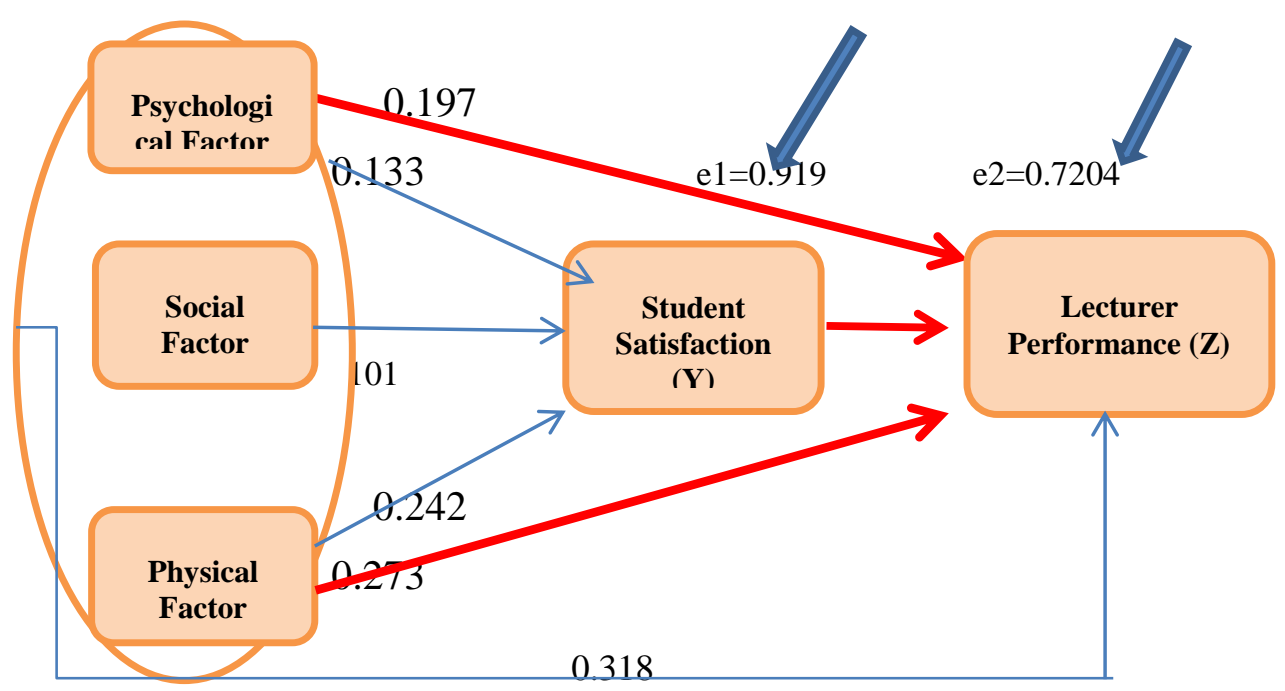

Figure 3 Regression Result of Model II

\subsection{Discussion}

a) Analysis of the influence of psychological factors on student satisfaction: from the analysis obtained a significance value of $\mathrm{X} 1$ of $0.051=0.05$, indicating that there is a significant direct effect of $\mathrm{X} 1$ on Y. While the analysis of the influence of psychological factors on lecturer performance obtained a significance value of $\mathrm{X} 1$ of $0.000<0.05$, So it can be concluded that there is a significant direct effect of $\mathrm{X} 1 \mathrm{on} \mathrm{Z}$. The direct effect of $\mathrm{X} 1$ on lecturer performance is 0.197 . While the indirect effect of $\mathrm{X} 1$ through $\mathrm{Y}$ on $\mathrm{Z}$ is the multiplication between the beta value of $\mathrm{X} 1$ to $\mathrm{Y}$ with the beta value of $\mathrm{Y}$ to $\mathrm{Z}$, namely: $0.133 \times 0.111=0.015$. Then the total effect given by $\mathrm{X} 1$ to $\mathrm{Z}$ is the direct effect plus the indirect effect, namely: $0.197+0.015=0.212$.

b) Analysis of the influence of social factors on student satisfaction: from the analysis obtained a significance value of X2 of $0.175>0.05$, and it can be concluded that the influence of $\mathrm{X} 2$ is not significant and directly affects Y. While the analysis of the influence of social factors on lecturer performance obtained a significance value of X2 of $0.000<0,05$, so it can be concluded that there is a significant direct effect of $\mathrm{X} 2$ on $\mathrm{Z}$. The direct effect of $\mathrm{X} 2$ on lecturer performance is 0.318 . While the indirect effect of $\mathrm{X} 2$ through $\mathrm{Y}$ on $\mathrm{Z}$ is the multiplication between the beta value of $\mathrm{X} 2$ on $\mathrm{Y}$ with the beta value of $\mathrm{Y}$ on $\mathrm{Z}$, namely: $0.318 \times 0.111=0.035$. Then the total effect given by $\mathrm{X} 1$ to $\mathrm{Z}$ is the direct effect plus the indirect effect, namely: $0.318+0.035=0.353$.

c) Analysis of the influence of physical factors on student satisfaction: the analysis obtained a significance value of X3 of $0.002<0.05$. it can be concluded that there is a significant effect of $\mathrm{X} 3$ on $\mathrm{Y}$. While the analysis of the influence of physical factors on lecturer performance obtained a significance value of $\mathrm{X} 3$ of $0.000<0.05$, so it can be concluded that there is a significant effect of $\mathrm{X} 3$ on $\mathrm{Z}$. The direct effect of $\mathrm{X} 3$ on lecturer performance is equal to 0.273 . At the same time, the indirect effect of $X 3$ through $\mathrm{Y}$ on $\mathrm{Z}$ is the multiplication between the beta value of $\mathrm{X} 3$ to $\mathrm{Y}$ with the beta value of $\mathrm{Y}$ to $\mathrm{Z}$, namely: $0.273 \times 0.111=0.03$. Then the total effect given by $\mathrm{X} 3$ to $\mathrm{Z}$ is the direct effect plus the indirect effect, namely: $0.273+0.03=0.303$.

From a series of discussions on the results of the analysis providing answers, there is an influence of psychological factors, social factors and physical factors on student satisfaction 
which have an impact on the performance of lecturers at private universities in the city of Palembang. This shows that the hypothesis $(\mathrm{Ha})$ is proven and can be accepted.

\section{Conclusion}

Based on the results of research and discussion, it can be concluded that psychological factors have a significant effect on student satisfaction at private universities in Palembang City. There is an indirect influence on psychological factors (X1) through student satisfaction (Y) on lecturer performance $(Z)$, and social factors have a significant effect on student satisfaction at private universities in Palembang City. There is an indirect influence on social factors (X2) through student satisfaction (Y) on lecturer performance (Z). Physical factors have a significant effect on student satisfaction at private universities in Palembang City, and there is also an indirect influence on physical factors (X3) through student satisfaction (Y) on lecturer performance $(\mathrm{Z})$

Based on the conclusions obtained from the analysis results, This research can bring benefits for private universities in Palembang City to pay more attention to physical factors and social factors and improve psychological factors to support student satisfaction to increase student confidence to foster loyalty. Excellent and positive perceptions of the teaching and learning process have an impact on the performance of lecturers, which in turn can strengthen the existence and reputation of private universities and increase the competitiveness of private universities in the city of Palembang and pay attention to indicators of social factors in the university environment in terms of creating a harmonious relationship between students and lecturers and between students and faculty. Employees will provide a comfortable and conducive atmosphere in the teaching and learning process so that students feel comfortable and enthusiastic in learning and will be satisfied to have lecturers who not only teach but can also be good mentors, understand the situation and conditions of students, appreciate and motivate students to create brilliant academic achievements to bring a good reputation and will become a higher education institution that so that it becomes a priority choice in the future.

\section{Reference}

Bintoro and Daryanto. (2017). Employee performance. Kencana.

Busro, M. (2018). Human Resource Management Theories. Prenadameidia Group.

Hasibuan, M. S. P. (2019). Human Resource Management. Bumi Aksara.

Norianggono, Y. C. P., Hamid, D., Ruhana, I (2014). Effect of physical work environment and non-physical against employee performance (study on employees of PT. Telkomsel

Area III Java-Bali Nusra in Surabaya). Journal of Business Administration, 8,(2), 1-10.

DOI: http://administrasibisnis.studentjournal.ub.ac.id/index.php/jab/article/view/383

Priansa, D. J. (2018). HR Planning \& Development. Alphabeta.

Spector. (1997). Job satisfaction: Application, assessment, causes and consequences, Thousand Oaks. Sage Publications, Inc.

Robbins, S. P. (2006). Organizational Behaviour. $10^{\text {th }}$ Edition, Translated By Benyamin 
Molan,Drs. Erlangga.

Sutrisno, E. (2009). Human Resource Management. 1st Edition. Kencana

Sutrisno, E. (2017). Human Resource Management. 9th Edition. Kencana.

Syaharuddin, S. (2016). Factors affecting employee job satisfaction Bank Muamalat Cab.

Samarinda. Journal.Feb.unmul, 13(1). DOI: http://dx.doi.org/10.29264/jkin.v13i1.363.

Wibowo. 2016. Work management, $5^{\text {th }}$ Edition. Rajagrafindo Publication

Verawati,Y and Saptarini. (2017). The Influence of Financial Factors, Social Factors and

Psychology Factors of Employee Performance at Lpd Kesiman Denpasar. Devotion Journal

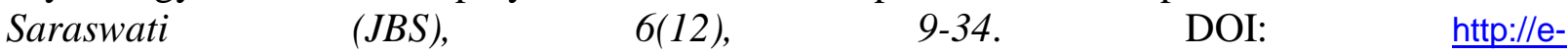
journal.unmas.ac.id/index.php/baktisaraswati/article/view/122

\section{Copyrights}

Copyright for this article is retained by the author(s), with first publication rights granted to the journal.

It is an open-access article distributed under the terms and conditions of the Creative Commons Attribution license (http://creativecommons.org/licenses/by/4.0/) 